Genetic Variation and

\section{Its Exploitation in White and Engelmann Spruce}

\author{
By L. ROCHE' and M. J. HOLST" and A. H. TEICH \\ ${ }^{1}$ Forest Reseorch Loborotory, Deportment of Fisheries and \\ Forestry, Quebec 10, Quebec. \\ "Petawawa Forest Experiment Station, Department of Fisheries \\ and Forestry, Chalk River, Ontario. \\ ODC 165.3
}

"Production per unit area of land can be increased by exploiting the genetic variation noithin a species even bofore the fruition of breeding programs."

\begin{abstract}
Genetic variation in white and Engelmann spruce (Picea glauca (Moench) Voss and P. engelmannii Parry) reported in the literature is revieved, and proposals are made to use this information to increase productivity in current forestry practice and to direct future research.

Because research in the genetic variation of these species has only recently been initiated, it will talie decades before the products of breeding can be utilized. The best way to exploit genetic variation in the species during the long waiting period between the initiation of a breeding program and the attainment of its objectives is to (1) demarcate seed zones, (2) establish seed production areas, (3) maintain a seed register and, (4) locate nurseries in appropriate climatic zones (match provenance with nursery). The forester who follows these practices will likely succeed in producing a productive man-made forest.
\end{abstract}

\section{Résumé}

Utilisation de la Variation Génétique chez l'Epinette Blanche (Picea glauca (Moench) Voss) et I'Epinette d'Engelmann (Picea engelmannii Parry)

Après avoir complété une revue de la littérature sur la variation génétique chez ces deux sortes d'épinettes, les auteurs proposent certaines recommandations, soit dans le but d'augmenter l'efficacité de nos pratiques courantes de foresterie, soit pour orienter les travaux de recherches à venir. Les recherches sur la variation génétique de ces deux essences sont à peine au stade initial;

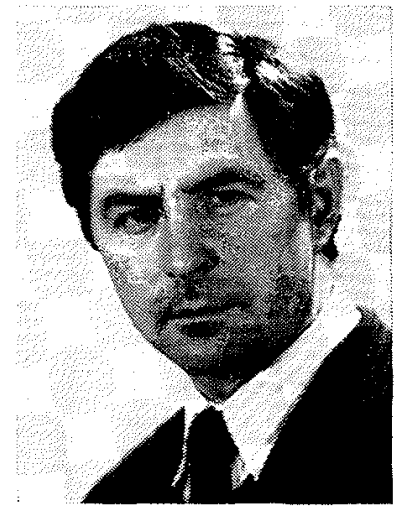

plusieur's décennies s'écouleront avant que les résultats cle ces hybridations puissent être employés.

La meilleure façon de tirer profit de la variation génétique de ces essences, durant cette longue période d'attente des résultats serait: a) de délimiter des zones à graines, $b$ ) d'établir des réserves pour la production de graines, c) de maintenir un registre sur l'origine des graines, d) d'établir. des pépinières à l'intérieur de zones climatiques (associer les pépinières avec les provenances). C'est en suivant ces recommandations que le forestier réussira dans l'installation de bonnes forêts artificielles.

The objectives of this article are: (1) to review published and unpublished information on white and Engelmann spruce, (2) to propose ways by which the present state of knowledge can be used immediately to increase forest productivity and (3) to suggest the direction future research should take.

\section{Genetic variation}

White and Engelmann spruce are the extreme forms of a clinal pattern of variation, and where they occur sympatrically, no major discrete morphological, physiological or chemotaxanomic differences between them has yet been determined (Roche 1969a). White spruce grows in every province and territory of Canada while Engelmann spruce occurs only in British Columbia and western Alberta. In Western Canada white spruce typically occurs at low elevations and Engelmann spruce at high elevations, while at intermediate elevations the species hybridize. The clinal pattern of variation 
in the white-Engelmann complex in the broad transitional zone between the Montane and Subalpine forest regions is the result of this hybridization followed by natural selection within the hybrid swarms. (Fig. 1).

The evolutionary process has, in certain instances, produced populations of exceptional value. In British Columbia, south of latitude $52^{\circ} 00$; there are small, vigorous introgressed populations (Roche $1969 \mathrm{~b}$ ), and one, the Birch Island provenance (latitude $51^{\circ} 37^{\prime}$; elevation $400 \mathrm{ft}$.) has grown vigorously in Eastern Canada and Norway, far from its origin. Evolution has also resulted in genetic differentiation of races across the species range. This differentiation is the basis for provenance research, the purpose of which is to identify and conserve valuable populations for use in tree breeding and production of man-made forests.

White spruce also hybridizes with $\mathbf{P}$. sitchensis (Bong.) Carr. in British Columbia where their ranges overlap along the Skeena and Nass River basins and along valley bottoms (Roche 1966, 1968a, 1969a). The cone morphology of the whiteSitka hybrid is very similar to that of pure Engelmann spruce; this may explain a reported occurrence (Garman 1957) of Engelmann spruce in the Skeena valley (Roche 1969a). Daubenmire (1968) found that the hybrid in this region is between white and Sitka and not white and Engelmann. There is evidence that white spruce also hybridizes with black spruce (P. mariana (Mill.) BSP.) in northern British Columbia (Roche 1965, 1966, 1968a, 1969a).

During the last 20 years, numerous trials of small numbers of provenances from west of the Rocky Mountains have been established in eastern Canada and northeastern United States (Holst 1955. 1960, 1969; Genys 1965; Nienstaedt 1968). However, there are very few studies of heritability in white spruce, and none in Engelmann spruce.

Provenance studies have shown that the local provenance is not necessarily the most productive. Of 25 white spruce provenances in a field test at Harrington, Quebec, the local provenance grew the least in height, while in a similar study in a nursery at Chalk River, Ontario, the local provenance was 5 percent shorter than the best introduced provenance (Holst 1969; Teich 1969a). However, in the absence of reliable information supporting seed introduction one ought to use local seed in establishing forest plantations, and this seed should, where possible, be collected only from phenotypically superior trees.

Improvement in white spruce productivity has also been demonstrated by individual tree selection. Teich (1969a), in a study of progenies of 17 plus trees, observed that selection of trees from a locally adapted population may be more productive than provenance introduction. Holst and Teich (1969) found that slender crowned plus trees were four percent taller than broad crowned plus trees and produced progeny that were four percent taller than the progeny of broad crowned trees. Heritability of height and leader number were 91 and 85 percent respectively. In a study of four-year-old half-sib families and their female parents Jeffers (1968) also found a positive correlation between parents and progeny with respect to current annual and total height growth. He concluded that phenotypic selection in white spruce was feasible and could result in an increase in merchantable timber volume of more than 21 percent.

Flushing and dormancy in pure white spruce, as in the white-Engelmann complex in Western Canada, are adaptive characteristics, and populations from different ecological zones exhibit differences in dates of flushing, growth cessation and dormancy even when grown in a common environment. Temperature, photoperiod and winter chilling are the principal environmental factors influencing these characteristics in white and Engelmann spruce (Vaartaja 1959, Nienstaedt 1967, Roche 1969a). Nienstaedt and King (1969), who estimated heritability of time of flushing in white spruce, have suggested the possibility of simultaneous selection for late flushing and rapid growth rate in this species.

White spruce ecotypes exist which grow well on limestone sites but have poor growth on base deficient soils (Anonymous, 1969). Consequently, when choosing a seed source, soil characteristics of the seed collection site should be matched with those of the planting area.

Teich (1969b) demonstrated that female flower color in white spruce is controlled by a single gene with two alleles. Allelic frequencies can be used to estimate the degree of inbreeding or random mating in white spruce populations.

\section{Exploitation}

Production per unit area of land can be increased by exploiting the genetic variation within a species even before the fruition of breeding programs. This can be accomplished by the demarkation of seed zones, by the establishment of seed transfer rules and by the development of seed production areas. At present there is not enough information con-

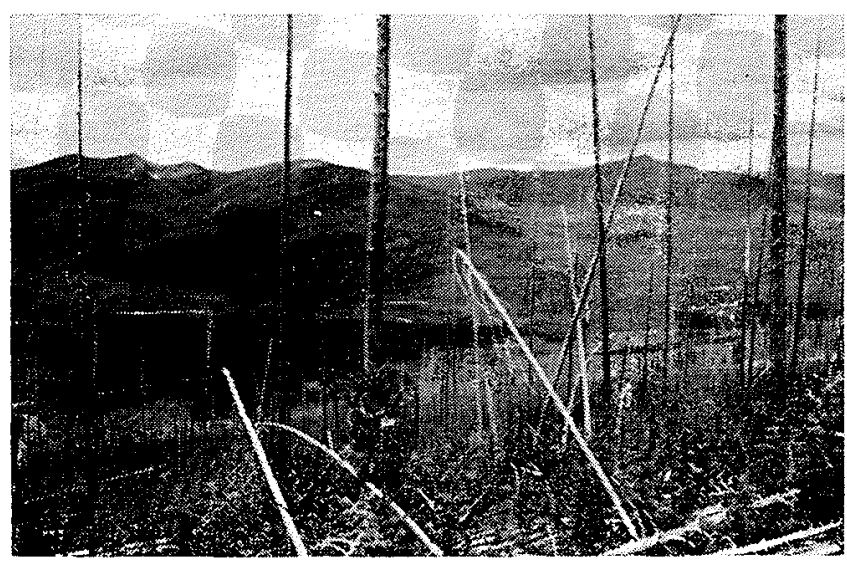

Fig. 2. Logged and burned Engelmann spruce stand regenerating to lodgepole pine. Twenty-five miles southwest of Cranbrook, B.C. Elevation 5,600 ft. 

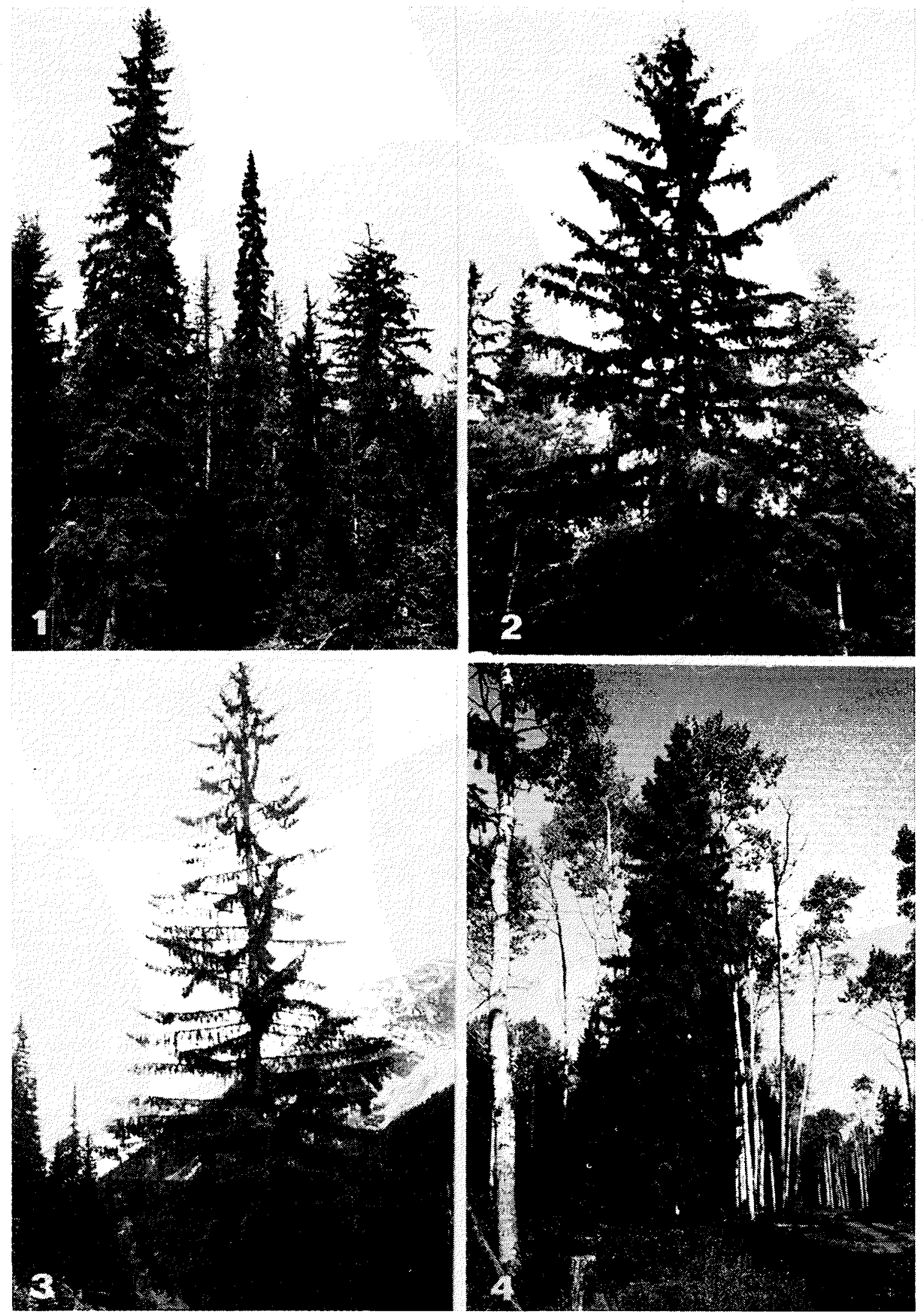

Fig. 1.-- Diverse branching habit in the white-Engelmann spruce complex in British Columbia. With the exception of number 4 , the forms illustrated are analogous to those described by Priehauisser (1958) for Narway spruce. (1) Plate spruce (typical branching habit, left and center of photo), 38

miles west of Needles, elevation 4,100 ft. (2) Brush spruce, 48 miles northwest of Smitters, elevation 1,200 ft. (3) Comb spruce, 18 miles northwest of Nelson, elevation 4,425 ft. (4) mutant farm, 30 miles north of Kamloops, elevation 3,500 ft. (Rache 1965). 
cerning geographic variation in white and Engelmann spruce to permit the demarkation of seed zones; however, it is possible to establish some guidelines for seed transfer. These guidelines have been drawn up (Roche 1969a; 1969b; Morgenstern and Roche 1969) and should be employed until better guidelines become available. Seed production areas will provide more reliable seed than random collections in natural forest stands. Seed production areas are established by selecting phenotypically superior stands within the appropriate seed zone or within the limits provided by the seed transfer rules. Individual trees within this stand which are below average in phenotypic value can be removed, and the remainder managed to promote seed production. Pitcher (1966) studied the costs and benefits of white spruce seed production in the United States and concluded that "while initial establishment and operating costs for white spruce seed production areas may seem high, analysis of total program costs in relation to benefits received indicates a sound investment."

\section{Literature cited}

Anonymous. 1969. Petawawa Forest Experiment Station program review 1967 and 1968. Canadian Forestry Service. 59 p.

DAUBERMIRE, R. 1968. Some geographic variations in Picea sitchensis and their ecologic interpretation. Can. Jour. Bot. 46: 787-797.

GARMAN E.H. 1957. The occurrence of spruce in the interior of British Columbia. Technical publication T 49, Dept. of Lands and Forests, B.C. For. Ser. 31 p.

GENYS, J.B. 1965. Growth potentials of fifteen provenances of white spruce from Canada, tested in Maryland. Chesapeake Sci. 6: 82-85.

HOLST, M.J. 1955. Some provenance and selection problems in eastern Canadian tree breeding. Pulp and Paper Magazine of Canada. Nov. 1955. 18-19, 23. 1960. Genetics as a factor in quality control. Pulp and Paper Magazine of Canada 61: 140-144.

1969. White spruce provenance experiments in eastern Canada. Unpublished manuscript. Forest Experiment Station, Chalk River, Ontario.

HOLST, M.J. and TEICH, A.H. 1969. Heritability estimates in Ontario white spruce. Silvae Genetica 18: 23-27.

JEFFERS, R.M. 1968. Parent-progeny growth correlations in white spruce. Proceedings of the Eleventh Meeting of the Committee on Forest Tree Breeding in Canada. MacDonald College, Aug. 8-10, 1968. 213-221.

MORGENSTERN, E.K., and L. ROCHE. 1969. Using concepts of selection to delimit seed zones. Second World Consultation on Forest Tree Breeding, Washington, Aug. 716. 1969. $8 \mathrm{p}$.

NIENSTAEDT, H. 1967. Chilling requirements in seven Picea species. Silvae Genetica 16: 65-68.

1968. Variation and adaptive stability of white spruce, Picea glauca (Moench) Voss seed sources. Proceedings of the Eleventh Meeting of the Committee on

\section{Future research}

Seed should be collected throughout the natural ranges of white and Engelmann spruce in Canada and the United States and used in range-wide provenance tests in accordance with the recommendations of the International Union of Forest Research Organizations. The massive production of planting stock will require considerable interprovincial cooperation. This study, if successful will allow the demarkation of seed zones, will identify superior races for seed transfer and will serve as a gene bank for the preservation and use of valuable races which otherwise may be harvested out of existence.

Heritability of economic characteristics within both species must be studied and understood to allow genetic improvement beyond that obtainable by seed transfer or by management of seed production areas. To date, very few such studies exist in white spruce, and probably none exist in Engelmann spruce. These studies can take the form of single tree progeny studies carried out in conjunction with the provenance studies.

Forest Tree Breeding in Canada. MacDonald College, Aug. 8-10, 1968. 183-194

- and JAMES P. KING. 1969. Breeding for delayed budbreak in Picea glauca (Moench) Voss - potential frost avoidance and growth gains. Second World Consultation on Forest Tree Breeding, Washington Aug. 7-16, 1969. $14 \mathrm{p}$.

PITCHER, J.A. 1966. Cone and seed yields in white spruce seed production areas. Research paper NC.6, 76-77, North Central Forest Experiment Station.

ROCHE, L. 1965. A note on spruce branching habit and bark type. B.C. For. Ser. Res. Rev. for year ended March 1965. 44-47.

1966. Geographic variation in spruce cone scale morphology. B.C: For. Res. Rev. for year ended March 1966. 40-43.

1968a. The value of short term studies in provenance research Com. For. Rev. 47: 14-26.

$1968 \mathrm{~b}$. Introgressive hybridization in the spruce species of British Columbia. Proceedings of the Eleventh Meeting of the Committee on Forest Tree Breeding in Canada. MacDonald College, Quebec, Aug. 8-10, 1968. 249-270.

1969a. A genecological study of the genus Picea in British Columbia. New Phytologist 68: 505-554. 1969b. The silvicultural significance of geographic variation in the white-Engelmann spruce complex of British Columbia. For. Chron. (in press).

$\mathrm{TElCH}$, A.H. 1969a. Genetic improvement of white spruce by provenance and individual tree selection. Unpublished manuscript. Petawawa Forest Experiment Station, Chalk River, Ontario.

1969b. Genetic control of female flower colour, and random mating in white spruce. Unpublished manuscript. Petawawa Forest Experiment Station, Chalk River, Ontario.

VAARTAJA, O. 1959. Evidence of photoperiodic ecotypes in trees. Ecological Monographs, 29: 91-111. 